\title{
Effect of Nine Black Soybean (Glycine max $l$.) Genotypes in Three Harvesting Time on Yield in Two Seasons
}

\author{
Omer A. Mohamed ${ }^{1, *}$, Sumadi ${ }^{2}$, Kamaleldin E. M. A. Taha ${ }^{3}$, Mohamed A. Mohammedali ${ }^{1}$, Mohieldin \\ G. Abdala ${ }^{3}$ \\ ${ }^{1}$ Department of Agronomy, Faculty of Agriculture, Omdurman Islamic University, Sudan. \\ ${ }^{2}$ Department of Agronomy, Faculty of Agriculture, Universitas Padjadjaran, Jl. Raya Bandung- Sumedang KM. 21 Jatinangor, \\ Indonesia. \\ ${ }^{3}$ Department of Horticulture, Faculty of Agriculture, Omdurman Islamic University, Sudan.
}

\begin{abstract}
How to cite this paper: Omer A. Mohamed, Sumadi, Kamaleldin E. M. A. Taha, Mohamed A. Mohammedali, Mohieldin G. Abdala. (2021) Effect of Nine Black Soybean (Glycine max l.) Genotypes in Three Harvesting Time on Yield in Two Seasons. International Journal of the Science of Food and Agriculture, 5(1), 19-25.

DOI: $10.26855 /$ ijfsa.2021.03.004
\end{abstract}

Received: November 28, 2020

Accepted: December 25, 2020

Published: January 11, 2021

*Corresponding author: Omer A. Mohamed, Department of Agronomy, Faculty of Agriculture, Omdurman Islamic University, Sudan.

Email: omerbz99@gmail.com

\begin{abstract}
The aim of this study was to know the production of nine black soybean genotypes correlation with three harvesting times. The experiments were conducted at the Universitas Padjadjaran, top farm Indonesia from December 2015-April 2016 and April-July 2016. The treatments were nine black soybean genotypes (KA6, KH4, CK5, KA2, KA3, DETAM1, KBI, CK6 and CIKURAY) and three harvesting times $(\mathrm{H} 1=$ first, $\mathrm{H} 2=$ second and $\mathrm{H} 3=$ third harvesting time $)$ with three replications in split plot design. Parameters which were measured pods/plant, total seeds/plant, weight seeds/plant, 100 seeds weight and plant production ton/hectare. The results showed in two seasons significant different between genotypes in full pods, total seeds/plant, a weight of seeds/plant, 100 seeds weight, and plant production ton/hectare and no significant different between genotypes in empty pods/plant. For three harvesting times, no significant different in two seasons for the entire production component. The results showed different between two seasons in plant production, where high genotypes production in the wet season than in dry season.
\end{abstract}

\section{Keywords}

Black soybean, genotypes, harvesting time, production

\section{Introduction}

Soybean Production by Country (Values in Metric Tons) United States: 108,014,000; Brazil: 95,500,000; Argentina: 55,000,000; Other: 1,900,500; China: 11,800,000; India: 10,500,000; Paraguay: 8,500,000; Canada: 6,050,000 [1]. Soybean is widely grown in the world such as in the USA throughout the densely populated island of Java, where $80 \%$ of Indonesia's total soybean area is concentrated. A similar proportion of the country's total soybean production is also in Java. Most of the major producing areas in Java are located in the drier part of the island, in districts receiving 1,500-2,100 mm of rain each year, and with 5 to 6 months with less than $100 \mathrm{~mm}$ of rain. The wet season is normally from November/December to March/April. Soybean is often planted in paddy fields in April after the main rice harvest and is harvested in early July. The main rice crop and then planted in December. The profitable yields can be obtained through genetic improvement for high yield potential. The examination of genetic diversity is important for plant breeder in general and particularly in a newly introduced crop like soybean. Introgression of diverse germplasm into the current soybean genetic base may increase genetic variability and lead to greater gains from selection [2]. Individual soybean genotypes often show restricted adaptation to specific agro-climatic environments [3]. However, information 
about late sowing in southwestern Japan is still limited. To select the most effective combination of growing season and cultivar, it is necessary to evaluate the growing season of new cultivars so as to achieve stable production of soybean [4]. Soybean is a major source of high-quality protein and oil, and soybean seed quality is often determined by seed protein, oil, fatty acid, and mineral content. Therefore, improving soybean seed quality is the key to improving human and animal nutrition. Soybean seed protein concentration ranges from 341 to $568 \mathrm{~g} \mathrm{~kg}-1$ of total seed weight, with a mean of $421 \mathrm{~g} \mathrm{~kg}-1$. Oil concentration ranges from $83 \mathrm{~g} \mathrm{~kg}-1$ to $279 \mathrm{~g}$ kg-1 with a mean of $195 \mathrm{~g}$ kg-1. Saturated fatty acids in soybean oil range from $100 \mathrm{~g} \mathrm{~kg}-1$ to $120 \mathrm{~g}$ kg-1 for palmitic acid, and from $22 \mathrm{~g} \mathrm{~kg}-1$ to $72 \mathrm{~g} \mathrm{~kg}-1$ for stearic acid. The mean concentration of unsaturated fatty acids is $240 \mathrm{~g} \mathrm{~kg}-1$ for oleic acid, $540 \mathrm{~g} \mathrm{~kg}-1$ for linoleic acid, and $80 \mathrm{~g} \mathrm{~kg}-1$ for linolenic acid. There was a negative relationship between elevated protein and oil concentration in soybean cultivars and yield and a negative correlation between protein and oil. Previous research has shown significant effects of production practices in soybean on protein and oil concentration of a soybean seed [5].

The study of their genetic diversity is invaluable for efficient utilization, conservation, and management of germ-plasm collections [6]. The genetic diversity is a key component of any agricultural production system. The material from the diverse geographical origin of the crop species can help to ensure conservation of co-adapted gene complexes [7] and [8]. The application of genetic variation can also be manipulated either for selecting superior genotypes or to be utilized as parents for the development of future cultivars through hybridization. Genetic improvements could be accelerated if physiological attributes were used as selection criteria [9]. A soybean with both high yielding and high concentrations of desired seed quality components is an ideal cultivar [8]. The objective of this study is to examine the yield stability of soybean promising lines with across environments in Indonesia. In the present study, the performance of 12 soybean genotypes over eight locations during the dry season 2012 was investigated using AMMI analysis. Environment (location) attributed the higher proportion of the variation (36\%), while the rests were genotype and GEI contributed $5.6 \%$ and $18.4 \%$ of total variation, respectively [10].

The harvesting time is one of the critical steps in soybean seeds production. unavoidable delays or those resulting from careless farmer's attention cause the exposition of the seeds to unfavorable environmental conditions and the acceleration of the deterioration process. Therefore, it is necessary to harvest at a time as close as possible to the physiological maturity, that is, after the stabilization of dry matter translocation to the seeds, when they reach the maximum germination and vigor potential. Soybeans should be harvested as soon as seed moisture comes to a level that allows mechanization. According to soybean seed deterioration in the field involves physical, physiological or microorganism caused alterations field deterioration is intensified by high temperatures or by moisture oscillations when respiration, lipid and protein degradation and microorganisms development increase and enzymatic activity are reduced and consequently, germination and vigor reductions are verified [11]. However, seed initial quality determined by its pre- and post-harvest history is fundamental. Verified the occurrence of mitochondrial function abnormalities and hence, respiratory rate decline, during the initial stages of soybean seeds deterioration. These alterations may be associated with lipid peroxidation, even before a pronounced reduction in germination and vigor are observed [12]. Physiological maturity or mass maturity occurred at around developmental stage R6 +15 days while maximum seed quality occurred five days later. Since farmers generally harvest soybean at around developmental stage R6 + 15 days, delaying harvest until sometime after mass maturity will ensure better seed quality. Seed quality as indicated by Ki value positively correlated with oligosaccharides, especially raff nose but negatively correlated with monosaccharide's as noted between seasons, among cultivars and harvest times [13]. Physiological maturity of seed is considered to occur when the seed has accumulated its maximum dry weight accumulation of seed dry weight and complete transition from green to yellow color. The percent moisture (wet-weight basis) of soybean seed at the maximum dry weight is variable, ranging from 50\%-62\%. There have been multiple attempts to describe PM of soybeans and the developmental stage when it occurs. Determine PM by correlating it with qualitative characteristics was reached at the reproductive development stage R7, described as "pods yellowing" and " $50 \%$ of leaves yellow". When one mature pod on the main stem was an acceptable indicator of PM and found that seed moisture at PM ranged from 54\%-62\% in soybeans. In the past, a common method for determination of PM of a single seed was to describe the seed as completely yellow, which was not useful for the determination of PM of the whole plant. The study usefulness of several visual indicators of PM determination, and concluded that results from their previous research proved to be a useful indicator in the determination of PM for a single plant or field population of soybeans. Change of color in the soybean hilum was found characterize PM, similar to the presence of an abscission layer (black layer) in corn. The loss of green color from pods may be a useful tool for prompt determination of PM. Seed shrinkage may also be a useful indicator PM in soybeans because seed shrinkage occurred immediately following the loss of green color in seeds [14].

Mention that Soybean yield components can be affected by several factors such [15]: shading and temperature, genotype and environmental conditions, seed vigor and seeding date, environment and cultivar [16]. The date of planting is one of the most critical cultural practices in soybean production. As planting is delayed during the summer season, time to maturity is shortened. Normally the life cycle duration of late varieties is reduced more than that of early varieties [17]. To understand the effect of the production environment (wet and dry seasons) and time of harvest on seed 
quality. Production environment affected seed quality, whereby seeds produced in the wet season had lower quality than those in the dry season, as indicated by lower seed potential longevity (Ki) [18] [19] [8]. The response of six soybean cultivars to the production environment on seed size and crop duration was similar. Generally, the time of planting varies depending on the climate condition of the region and the variety to be grown. Different varieties of soybean are sensitive to change to environment conditions where the crop is being grown [17] [20] [21]. This study aimed that the black soybean genotypes in three harvesting time in two season effecting on seeds yield.

\section{Methods}

\subsection{Time and place of the experiments}

Field deterioration is intensified by high temperatures or by moisture oscillations when respiration, lipid and protein degradation and microorganisms development increase and enzymatic activity are reduced and consequently, germination and vigor reductions are verified. However, seed initial quality determined by its pre- and post-harvest history is fundamental. Verified the occurrence of mitochondrial function abnormalities and hence, respiratory rate decline, during the initial stages of soybean seeds deterioration. These alterations may be associated with lipid peroxidation, even before a pronounced reduction in germination and vigor are observed [12]. The experiments were conducted at the farm Padjadjaran University Ciparanje Jatinangor, Sumedang Regency, West Java Province. Location trial was irrigated rice area at an altitude of $720 \mathrm{~m}$ above sea level, with an average rainfall of $175.3 \mathrm{~mm}$ per month and daily temperature $18.1^{\circ} \mathrm{C}$. There were pre-experiment were conducting to select genotypes which have high yield form nineteen genotypes for first and second experiments during December 2014 until March 2015. The first experiment begins in October 2015 and ends early January 2016 and the second experiment begin in later March and end in July 2016.

\subsection{First experiment in wet season}

There were cultivating nine lines of soybean genotypes: (1) KH 4; (2) KBI; (3) CK 5; (4) CK 6; (5) KA 2; (6) KA 3; (7) KA 6; (8) CIKURAY; (9) DETAM 1. This experiment designing in split plot design These genotypes were main plots and subplots three-time of harvesting. $\mathrm{H} 1$ harvesting after physiological maturity when the pods beginning to change color from green to yellow, H2 harvesting after full change in color and H3 harvesting after the full maturity and the pods lost its moisture contents, with three replications (R1, R2, and R3), each plot consisting of 6 rows each of 300 $\mathrm{cm}$ in length and width $200 \mathrm{~cm}$ with a row to row distance $40 \mathrm{~cm}$ with $15 \mathrm{~cm}$ of plant space and the space between plots $100 \mathrm{~cm}$. The crop was grown under field conditions. Land preparing manuals to make plots. Before sewing add pesticide powder in the holes this sowing is done by hand. The irrigation depended on rain. Weeds control by manuals. Randomly selection plants for samples. The samples were hold to the green house for drying. Then storage in the storage room is under $25^{\circ} \mathrm{C}$ for 90 days.

\subsection{Second experiment in dry season}

There were cultivate nine lines of soybean genotypes: (1) KH 4; (2) KBI; (3) CK 5; (4) CK 6; (5) KA 2; (6) KA 3; (7) KA 6; (8) CIKURAY; (9) DETAM 1. This experiment designing in split plot design. These genotypes were main plots and subplots three-time of harvesting. H1 harvesting after physiological maturity when the pods beginning to change color from green to yellow, $\mathrm{H} 2$ harvesting after full change in color and $\mathrm{H} 3$ harvesting after the full maturity and the pods loss its moisture contents, with three replications (R1, R2 and R), each plot consisting of 6 rows each of $300 \mathrm{~cm}$ in length and width $200 \mathrm{~cm}$ with a row to row distance $40 \mathrm{~cm}$ with $15 \mathrm{~cm}$ of plant space and the space between plots 40 $\mathrm{cm}$. The crop was grown under field conditions. Land preparing manuals to make plots. Before sewing add pesticide powder in the holes this sowing is done by hand. The irrigation depended on rain. Weeds control by manuals. Randomly selection plants for samples. The samples were hold to the green house for drying. Then storage in the storage room under $25^{\circ} \mathrm{C}$ for 90 days.

\subsection{The tools}

Soybean seeds (Glycine max (L.) Merr.) were procured from the Department of Plant Breeding and Genetics, Padjadjaran University Indonesia. The crop was raised in the fields of Department of Plant Breeding and Genetics, the following recommended Package of Practices which seeds produce in March 2015 and checking the germination before storage in Laboratory under the room temperature $18^{\circ} \mathrm{C}-25^{\circ} \mathrm{C}$. Tools for cultivation equipment required starting from land preparation to harvesting consists of hoes, cored, drill, buckets, rope, plastic bags and other supporting equipment. It also takes some observation equipment in the field such as a ruler, meters, the equipment documentation, labels, and laptop. 


\subsection{Methods and Design of Experiments}

The experimental design use is (split-plot design) is replication three times. The main plot factor is genotypes performance composing nine line and subplots consisting of three times of harvesting.

a. The main plot is nine genotypes (G) namely: (1) KH 4; (2) KBI; (3) CK 5; (4) CK 6; (5) KA 2; (6) KA 3; (7) KA 6; (8) CIKURAY; (9) DETAM 1.

b. The subplots three harvesting times $(\mathrm{H})$ where $\mathrm{H} 1$ harvesting after physiological mature directly, H2 after physiological maturity and changing in color and $\mathrm{H} 3$ after physiological maturity, changing in color and loss the water.

\subsection{Parameters measured of Agronomic Components}

Number of pods per plant, number of seeds per pod, number of seeds per plant, weight of seeds per plant, Means. 10seed weight, Seed weight Ton/h, Split plots design were conducted and data Analysis with SPSS and partly test for season.

\section{Results}

In wet season full pods/plant result showed significant different between genotypes, where high full pods/plant were KA2 56.473 pods, low full pods/plant were KA3 36.678 pods. In three harvesting time, it has no significant different, where H1 46.03 pods, H2 47.82 pods and H3 48.43 pods. Empty/plant the result showed no significant different between the genotypes where high empty pods/plant were KA2 3.763 empty pods, low empty pods were KA3 1.962 empty pods. In three harvesting times, no significant different where H1 2.921 empty pods, H2 1.682 empty pods, H3 2.496 empty pods. Total seeds/plant the result showed significant different between genotypes where high total seed/plant was KA6 136.44 seeds/plant and low was KA3 72.96 seeds. In three harvesting times, there was no significant different among genotypes where H1 101.83 seeds, H2 105.96 seeds/plant, and H3 107.09 seeds/plant. Weight of seeds/plant the result showed significant different between genotypes where high weight of seeds/plant was DETAM1 15.217 gram and low was CK6 9.107 gram. Harvesting time had significant different where H1 10.867 gram, H2 12.65 gram and H3 11.933 gram. Weight of 100 seeds the result revealed significant different between the genotypes where high 100 seeds weight was KA3 15.323 gram and low 100 seeds weight was CK6 9.851 gram. In three harvesting times, there was no significant different where H1 11.91 gram, H2 12.09 gram and H3 12.05 gram. Yield ton/h in wet season the result showed significant different between genotypes where high yield ton/h was DETAM1 2.029 ton/h and low was CK6 1.216 ton/h. Harvesting time had no significant different where H1 1.450 ton/h, H2 1.685 ton/h and H3 1.592 ton/Ha (Table 1 and Table 3).

In dry season, the result showed that significant different between genotypes in full pods per plant, where the high full pods per plant was KBI 54.23 pods, low full pods were KA3 28.63 pods. In harvesting time, there were no significant different between three times of harvesting, where H1 44.31 pods, H2 43.15 pods, H3 43.44 pods (Table 1). Empty pods the result shows no significant different between genotypes. In dry season, high empty pods was KBI 5.07 and low was KA6 3.30. In harvesting time, there were no significant different between genotypes where H1 5.61 pods, H2 4.55 pods, and H3 4.04 pods. The result revealed significant different between genotypes in number of seeds per plant, where high total of seeds per plant was CIKURAY 113.13 seeds, low number of seeds per plant was KA3 44.58 seeds. In three harvesting times, there were no significant different between genotypes, where H1 82.82 seeds, H2 81.78 seeds, and H3 80.61 seeds (Table 1). In weight of seed per plant, the result showed significant different between the genotypes, where high weight seeds per plant were CIKURAY 15.003 gram, low weight seeds per plant was KA3 6.790 gram. Harvesting time showed no significant different in three harvesting time where H1 10.204 gram, H2 9.895 gram and H3 9.642 gram (Table 1).Weight of 100 seeds the result showed significant different between the genotypes, where high 100 seeds weight was KA3 15.51 gram, low weight of 100 seeds per plant was KA2 9.93 gram. There were no significant different at three harvesting time H1 12.76 gram, H2 13.01 gram and H3 12.38 gram. Plant production ton/h showed significant different between the genotypes. High plant production was CIKURAY 2,014 ton/h, low plant production was KA3 0.905 ton/Ha. In harvesting time, there was no significant different, where H1 1.36 ton/h, H2 1.31 ton/h and 1.28 ton/h (Table 1 and Table 3). In wet season, full pods/plant result showed significant different between genotypes, where high full pods/plant were KA2 56.473 pods, low full pods/plant were KA3 36.678 pods. In three harvesting times, there was no significant different, where H1 46.03 pods, H2 47.82 pods and H3 48.43 pods. Empty/plant the result showed no significant different between the genotypes where high empty pods/plant were KA2 3.763 empty pods, low empty pods were KA3 1.962 empty pods. In three harvesting times no significant different where H1 2.921 empty pods, H2 1.682 empty pods, H3 2.496 empty pods. Total seeds/plant the result showed significant different between genotypes where high total seed/plant was KA6 136.44seeds/plant and low was KA3 72.96 seeds. In three harvesting times, there was no significant different between genotypes where H1 101.83 seeds, H2 105.96 seeds/plant, and H3 107.09 seeds/plant. Weight of seeds/plant the result showed significant different between genotypes where high 
weight of seeds/plant was DETAM1 15.217 gram and low was CK6 9.107 gram. Harvesting time had significant different where H1 10.867 gram, H2 12.65 gram and H3 11.933 gram. Weight of 100 seeds the result revealed significant different between the genotypes where high 100 seeds weight was KA3 15.323 gram and low 100 seeds weight was CK6 9.851 gram. In three harvesting times, there was no significant different where H1 11.91 gram, H2 12.09 gram and H3 12.05 gram. Production ton/h in wet season the result showed significant different between genotypes where high production ton/Ha was DETAM1 2.029 ton/Ha and low was CK6 1.216 ton/Ha. Harvesting time had no significant different where H1 1.450 ton/h, H2 1.685 ton/h and H3 1.592 ton/Ha (Table 1 and Table 3). Full pods in wet season most of genotypes showed high, but there were two genotypes (KBI and CIKURAY) showed low in wet season and highly in dry season. All of the three harvesting times revealed high in wet season. Compared showed low total empty pods in wet season for genotypes and three harvesting time. Compared between two seasons in total seeds per plant showed that showed that all the genotypes were high in wet season accept CIKURAY was low in this season than in dry season. Three harvesting time revealed high in total seeds per plant. Weight of seed per plant the result refered that there were different between seasons in wet season, there were genotypes high (KA6, KH4, CK5, KA3, DETAM 1 and CK6) than in dry season and this genotypes (KBI and CIKURAY) were low in wet season than in dry season. Three harvesting times showed different between seasons in weight of seeds per plant which high in wet season. Weight of 100 seeds the result showed for compared between genotypes in two seasons. Although there were genotypes high 100 seeds weights in dry season (KA6, KH4, CK5, KA3, DETAM 1, CK6 and CIKURAY), there were two genotypes revealed low 100 seed weight in dry season compared with wet season. This result showed significant heterogeneous between seasons in full pods, empty pods, weight of seeds per plant, yield Ton per hectare (Table 2).

Table 1. Yield Component in Two Seasons

\begin{tabular}{|c|c|c|c|c|c|c|c|c|c|c|c|c|}
\hline \multirow{2}{*}{ Treatments } & \multicolumn{6}{|c|}{ Wet Season } & \multicolumn{6}{|c|}{ Dry Season } \\
\hline & F.P/P & E. P/P & T.S/P & W. S/P & W.100S & $\mathrm{P} / \mathrm{T} / \mathrm{h}$ & F.P/P & E. P/P & T.S/P & W. S/P & W.100 S & $\mathrm{P} / \mathrm{T} / \mathrm{h}$ \\
\hline KA6 & $51.07^{\mathrm{bc}}$ & $2.56^{\mathrm{a}}$ & $136.44^{\mathrm{d}}$ & $12.09^{\mathrm{bc}}$ & $9.98^{\mathrm{a}}$ & $1.61^{\mathrm{bc}}$ & $45.18^{\mathrm{bc}}$ & $3.90^{\mathrm{a}}$ & $81.90^{\mathrm{b}}$ & $9.02^{\mathrm{a}}$ & $11.00^{\mathrm{b}}$ & $1.20^{\mathrm{a}}$ \\
\hline KH4 & $36.98^{\mathrm{a}}$ & $2.21^{\mathrm{a}}$ & $83.12^{\mathrm{ab}}$ & $10.66^{\mathrm{ab}}$ & $13.62^{\mathrm{b}}$ & $1.42^{\mathrm{ab}}$ & $30.73^{\mathrm{a}}$ & $5.12^{\mathrm{a}}$ & $50.04^{\mathrm{a}}$ & $7.24^{\mathrm{a}}$ & $15.18^{\mathrm{ef}}$ & $0.95^{\mathrm{a}}$ \\
\hline CK5 & $54.94^{\mathrm{bc}}$ & $3.02^{\mathrm{a}}$ & $118.08^{\mathrm{cd}}$ & $11.26^{\mathrm{abc}}$ & $9.88^{\mathrm{a}}$ & $1.50^{\mathrm{abc}}$ & $44.01^{\mathrm{bc}}$ & $4.85^{\mathrm{a}}$ & $78.02^{\mathrm{b}}$ & $7.84^{\mathrm{a}}$ & $10.45^{\mathrm{ab}}$ & $1.05^{\mathrm{a}}$ \\
\hline KA2 & $56.47^{\mathrm{c}}$ & $3.76^{\mathrm{a}}$ & $117.84^{\text {cd }}$ & $11.82^{\mathrm{bc}}$ & $10.28^{\mathrm{a}}$ & $1.58^{\mathrm{bc}}$ & $45.86^{\mathrm{bcd}}$ & $3.91^{\mathrm{a}}$ & $87.06^{b c}$ & $8.31^{\mathrm{a}}$ & $9.93^{\mathrm{a}}$ & $1.11^{\mathrm{a}}$ \\
\hline KA3 & $36.68^{\mathrm{a}}$ & $1.96^{\mathrm{a}}$ & $72.96^{\mathrm{a}}$ & $11.23^{\mathrm{abc}}$ & $15.32^{\mathrm{c}}$ & $1.51^{\mathrm{abc}}$ & $28.63^{\mathrm{a}}$ & $5.04^{\mathrm{a}}$ & $44.58^{\mathrm{a}}$ & $6.79^{\mathrm{a}}$ & $15.1^{\mathrm{f}}$ & $0.91^{\mathrm{a}}$ \\
\hline DETAM 1 & $51.22^{\mathrm{bc}}$ & $2.50^{\mathrm{a}}$ & $115.86^{\mathrm{cd}}$ & $15.28^{d}$ & $13.22^{\mathrm{b}}$ & $2.03^{d}$ & $50.63^{\text {cde }}$ & $5.06^{\mathrm{a}}$ & $101.54^{\mathrm{cd}}$ & $13.75^{\mathrm{b}}$ & $14.22^{\mathrm{C}}$ & $1.83^{\mathrm{b}}$ \\
\hline KBI & $47.33^{b}$ & $2.25^{\mathrm{a}}$ & $118.48^{\mathrm{cd}}$ & $13.37^{\mathrm{cd}}$ & $13.30^{\mathrm{b}}$ & $1.83^{\mathrm{cd}}$ & $54.23^{\mathrm{e}}$ & $5.07^{\mathrm{a}}$ & $107.36^{\mathrm{d}}$ & $13.96^{\mathrm{b}}$ & & $1.86^{\mathrm{b}}$ \\
\hline CK6 & $51.98^{\mathrm{bc}}$ & $2.56^{\mathrm{a}}$ & $96.79^{\mathrm{bc}}$ & $9.11^{\mathrm{a}}$ & $9.85^{\mathrm{a}}$ & $1.22^{\mathrm{a}}$ & $41.14^{\mathrm{b}}$ & $4.52^{\mathrm{a}}$ & $71.99^{\mathrm{b}}$ & $7.28^{\mathrm{a}}$ & & $0.97^{\mathrm{a}}$ \\
\hline CIKURAY & $40.21^{\mathrm{a}}$ & $2.59^{\mathrm{a}}$ & $85.07^{\mathrm{ab}}$ & $11.11^{\mathrm{abc}}$ & $12.68^{\mathrm{b}}$ & $1.48^{\mathrm{abc}}$ & $52.29^{\text {de }}$ & $5.02^{\mathrm{a}}$ & $113.13^{d}$ & $15.03^{\mathrm{b}}$ & $14.39^{\mathrm{de}}$ & $2.00^{\mathrm{b}}$ \\
\hline C.V & $19.21 \%$ & $6.8 \%$ & $18.44 \%$ & $18.2 \%$ & $7.6 \%$ & $18.2 \%$ & $20.15 \%$ & $47.24 \%$ & $28.8 \%$ & $32.2 \%$ & $6.9 \%$ & $32.4 \%$ \\
\hline H1 & $46.03^{\mathrm{a}}$ & $2.92^{\mathrm{a}}$ & $101.83^{\mathrm{a}}$ & $10.87^{\mathrm{a}}$ & $11.91^{\mathrm{a}}$ & $1.45^{\mathrm{a}}$ & $44.31^{\mathrm{a}}$ & $5.61^{\mathrm{b}}$ & $82.82^{\mathrm{a}}$ & $10.20^{\mathrm{a}}$ & $12.76^{\mathrm{a}}$ & $1.36^{\mathrm{a}}$ \\
\hline $\mathrm{H} 2$ & $47.82^{\mathrm{a}}$ & $1.68^{\mathrm{a}}$ & $105.96^{\mathrm{a}}$ & $12.65^{\mathrm{ab}}$ & $12.09^{\mathrm{a}}$ & $1.69^{\mathrm{a}}$ & $43.15^{\mathrm{a}}$ & $4.55^{\mathrm{a}}$ & $81.78^{\mathrm{a}}$ & $9.90 \mathrm{a}$ & $13.01^{\mathrm{a}}$ & $1.31^{\mathrm{a}}$ \\
\hline H3 & $48.43^{\mathrm{a}}$ & $2.50^{\mathrm{a}}$ & $107.09^{\mathrm{a}}$ & $11.93^{\mathrm{b}}$ & $12.05^{\mathrm{a}}$ & $1.59^{\mathrm{a}}$ & $43.44^{\mathrm{a}}$ & $4.04^{\mathrm{a}}$ & $80.61^{\mathrm{a}}$ & $9.64^{\mathrm{a}}$ & $12.38^{\mathrm{a}}$ & $1.28^{\mathrm{a}}$ \\
\hline C.V & $15.28 \%$ & $40.4 \%$ & $21.72 \%$ & $21.2 \%$ & $8.5 \%$ & $21.1 \%$ & $15.46 \%$ & $33 \%$ & $20 \%$ & $22.38 \%$ & $6.7 \%$ & $22.2 \%$ \\
\hline
\end{tabular}

F.P/P $=$ = Full pods per plant. E. P/P = Empty pods per plant. T.S/P = Total seeds per plant. W. S/P = Weight of seeds per plant. W.100S = Weight of 100 seeds. Yield ton per hectare. Different letters that means significant and similar letters means non-significant different according to DUNK test.

Table 2. Compared of Full pod, Empty pods, Seeds/plant, Weight of seed/plant, Weight of 100 seeds and Yield Ton/hin wet and dry seasons

\begin{tabular}{ccc}
\hline NO & Parameters & Lavenes test \\
\hline 1 & Full pods & Heterogeneous ${ }^{*}$ \\
3 & Empty pods & Heterogeneous $^{*}$ \\
5 & Total Seeds/plant & Homogeneous ${ }^{\text {NS }}$ \\
4 & Weight of seed/plant & Heterogeneous \\
5 & Weight of 100 seeds & Homogeneous ${ }^{\text {NS }}$ \\
6 & Production Ton/h & Heterogeneous \\
\hline
\end{tabular}

P-value $0,001<0.05$, heterogeneous, * significant , ${ }^{\text {NS }}$ no significant different.

This result showed significant heterogeneous between seasons in full pods, empty pods, weight of seeds per plant, yield Ton per hectare and seeds/plant. Weight of 100 seeds between two seasons is no-significant homogeneous. 
Table 3. Statistical Analysis of Yield Ton/Ha in Wet and dry Season

\begin{tabular}{ccccccccccc}
\hline $\begin{array}{c}\text { Seasons } \\
\text { Source of vaiace }\end{array}$ & d.f & Sum of Squares & Mean Square & F & Sig. & d.f & Sum of Squares & Mean Square & F & Sig. \\
\hline Replication & 2 & 3.823 & 1.912 & 23.19 & $0.000^{*}$ & 2 & 3.498 & 1.749 & 9.572 & $0.002^{*}$ \\
Genotype (G) & 8 & 4.012 & 0.502 & 6.084 & $0.001^{*}$ & 8 & 14.21 & 1.776 & 9.772 & $0.001^{*}$ \\
Error (g) & 16 & 1.319 & 0.082 & 0.735 & 0.742 & 16 & 2.932 & 0.183 & 2.088 & 0.033 \\
Harvesting time (H) & 2 & 0.76 & 0.38 & 3.388 & 0.045 & 2 & 0.076 & 0.038 & 0.435 & 0.651 \\
G X H & 16 & 1.113 & 0.7 & 0.62 & 0.846 & 16 & 0.708 & 0.44 & 0.506 & 0.927 \\
Error (h) & 36 & 4.037 & 0.112 & & & 36 & 3.15 & 0.087 & & 4.273 \\
Total & 80 & 15.064 & 3.688 & & & 80 & 24.574 & & \\
\hline
\end{tabular}

Note: sign * Significant in p-value 5\%

\section{Discussion}

Weight of seed per plant the result referred that there were different between seasons in wet season, there were genotypes high (KA6, KH4, CK5, KA3, DETAM 1 and CK6) than in dry season and this genotypes (KBI and CIKURAY) were low yield in wet season than in dry season similar with [17-19]. Three harvesting times showed different between seasons in weight of seeds per plant which high in wet season. This result showed significant heterogeneous between seasons in full pods, empty pods, weight of seeds per plant, yield Ton per hectare. Seeds/plant weight of 100 seeds between two seasons was no-significant homogeneous. Agree with [4] and [17] [20] [21], total seeds/plant was non-significant between two seasons.

\section{Conclusion}

An agronomic component in two seasons result showed significant different between genotypes in full pods, total seeds/plant, a weight of seeds/plant, 100 seeds weight, and plant production ton/hectare and no significant different between genotypes in empty pods/plant. For three harvesting times, there was no significant different in two seasons for all of the production components, the result showed different between two seasons in plant production, where high genotypes production in the wet season than in dry season.

\section{Acknowledgements}

We thank Agung for giving us the seeds of black soybean genotypes and his team. We thanks the top farm UNPAD university workers for helped us to complete this work.

\section{References}

[1] Zanetta, Chindyulima. (2014). Stability and adaptation on productivity and production components of black soybean genotypes in java Island. Thesis, Faculty of Agriculture, Padjadjaran University, Department of Agriculture Culture. https://www.researchgate.net/publication/271138214.

[2] Thompson, J. A. and R. L. Nelson. (1998). Utilization of diverse germplasm for soybean yield improvement. Crop Sci., 38: 1362-1368.

[3] Dlamini, A. P. (2015). Soybean (Glycine max L. Merr) productivity in varying agro-ecological zones. Dissertation (MSc Agric). University of Pretoria, South Africa. http://hdl.handle a. http://hdl.handle.net/2263/50882.

[4] Yohei Kawasaki, Ryo Yamazaki, and Katsuyuki Katayama. (2018). Effects of late sowing on soybean yields and yield components in southwestern Japan. Plant Production Science, 21: 4, 339-348, DOI: 10.1080/1343943X.2018.1511376.

[5] Bellaloui, Nacer, Bruns, H. Arnold, Gillen, Anne. M., Abbas, Hamed K., Zablotowicz, Robert M., Mengistu, Alemu, and Paris, Robert L. (2010). Soybean seed protein, oil, fatty acids, and mineral composition as influenced by soybean-corn rotation. Vol. 1, No. 3, 102-109 (2010). Agricultural Sciences. doi:10.4236/as.2010.13013.

[6] Dong, Y. S., B. C. Zhuang, L. M. Zhao, H. Sun, and M. Y. He. (2001). The genetic diversity of annual wild soybeans grown in Chi Theor. Appl. Genet., 103: s98-103.

[7] Frankel, O. H., A. D. H. Brown, and J. J. Burdon. (1995). The Conservation of Plant Biodiversity. Cambridge University Press, Cambridge, UK, p. 299.

[8] Mandi'c, Violeta. Snežana, Đordevi'c. Nikola, Đordevi'c. Zorica, Bijeli'c. Maja, Petricevi'c. Vesna, Krnjaja and Milan, Brankov. (2020). Genotype and Sowing Time Effects on Soybean Yield and Quality. Agriculture 2020, 10, 502; doi: 10.3390/agriculture10110502. www.mdpi.com/journal/agriculture. 
[9] Khan, Saleem, Latif, Abdul, Ahmad, Sahibzada Qayyum, Ahmad, Farhad, and Fida, Mehvish. (2011). Genetic Variability Analysis in Some Advanced Lines of Soybean (Glycine max L.). Asian Journal of Agricultural Sciences, 3(2): 138-141, 2011 ISSN: 2041-3890 @ Maxwell Scientific Organization.

[10] Krisnawati, Ayda, M. Muchlish Adie, and Gatut, Wahyu A. S. (2014). The Yield Stability of Indonesian Soybean Promising Lines with High Isoflavone for Food Security. Indonesian Legumes and Tuber Crops Research Institute, Malang, Indonesia International Conference on Nutrition and Food Sciences IPCBEE, Vol. 71 IACSIT Press, Singapore DOI: 10.7763/IPCBEE. 2014. V71. 29.

[11] Smith, J. R. and A. Mengistu. (2010). Seed quality of high-germinability soybean lines after six months of ambient storage. Crop Science Society of America. Abstract.

[12] Filho, J. Marcos, H. M. C. P. Chamma, J. R. R. Casagrande, E. A. Marcos. (1994). Effect of harvesting time on seed physiological quality, Chemical composition and storability of soybeans. Sci. Agric., Piracicaba, 51(2): 298-304, mayo/ago.

[13] Harnowo, Didik. (2004). Effect of time of harvest and seed size on seed quality of soybean. Abstract of thesis presented to the Senate of Universiti Putra Malaysia in fulfilment of the requirement for the Degree of Doctor of Philosophy.

[14] Ennen, Ross David. (2011). Earlier harvest and drying of soybean seed within intact pods maintains seed quality. Online at 5-june2015.http://lib.dr.iastate.edu/etd.

[15] Wei, Marcelo Chan Fu, and Molin, José Paulo. (2020). Soybean Yield Estimation and Its Components: A Linear Regression Approach. Agriculture 2020, 10, 348; DOI: 10.3390/agriculture100803.

[16] MacMillan, K. P., Guiden, R. H. (2020). Effect of seeding date, environment and cultivar on soybean seed yield, yield components, and seed quality in the Northern Great Plains. Agron. J. 2020, 112, 1666-1678.

[17] Bakal, Halil, Leyla Gulluoglu, Bihter Onat, Halis Arioglu. (2017). The effect of growing seasons on some agronomic and quality characteristics of soybean varieties in mediterranean region in Turkey. Turk Journal of Field Crops, 22(2), 187-196. DOI: 10.17557/tjfc.356213.

[18] Matsuo, N., K. Fukami, and S. Tsuchiya. (2016). Effects of Early Planting and Cultivars on the Yield and Agronomic Traits of Soybeans Grown in Southwestern Japan. Plant Production Science, 19(3): 370-380.

[19] Yila, Keiwoma Mark, Ernest Gibril Kamara, Augustine Mansaray, and Jenneh Fatima Bebeley. (2019). Agronomic response of soybean to first and second cropping season cultivation in different agro-climatic zones in Sierra Leone. International Journal of Agronomy and Agricultural Research (IJAAR), Vol. 14, No. 6, p. 59-68. ISSN: 2223-7054 (Print) 2225-3610 (Online). http://www.innspub.net.

[20] Yan Zhe, Joseph G. Lauer, Roger Borges, and Natalia de Leon. (2010). Effects of Genotype × Environment Interaction on Agronomic Traits in Soybean. Journal of Crop Science, Vol. 50.

[21] Helton Santos Pereira, Leonardo Cunha Melo, Maria José Del Peloso, Luís Cláudio de Faria, and Adriane Wendland. (2011). Complex interaction between genotypes and growing seasons of carioca common bean in Goiás/Distrito Federal Federal. Journal of Crop Breeding and Applied Biotechnology, 11: 207-215. Brazilian Society of Plant Breeding. Printed in Brazil. 